\title{
Origins of the Chilean Binominal Election System*
}

\author{
Daniel Pastor \\ PRINCETON UNIVERSITY
}

\begin{abstract}
Resumen
Se ha asumido que el presente sistema electoral chileno -el "binominal mayoritario"- fue una reacción ante la derrota del General Augusto Pinochet en el plebiscito de 1988, ya que fue lanzado en el intermedio después del plebiscito, pero antes que el régimen militar abandonara el poder. No obstante, esta hipótesis se equivoca en la historia de la evolución del sistema binominal que es más complejo. Este artículo explora la historia de los procesos políticos dentro del régimen militar y la ideología que llevó al sistema binominal. Argumenta que el sistema binominal fue la piedra arquitectónica de la institucionalidad autoritaria del régimen militar que protegía su Constitución de 1980 contra los esfuerzos de la Concertación para reformarla. Afirma que el sistema fue propuesto mucho antes del plebiscito de 1988 por Arturo Marín Vicuña, entonces el secretario de una comisión que estudiaba una nueva ley electoral, y fue producto más que nada de una interpretación de la historia política chilena entre 1960 y 1973 que fue ampliamente compartida entre los asesores jurídicos del gobierno militar.
\end{abstract}

\begin{abstract}
Many analysts and observers have assumed that the current Chilean binominal election system was a strategic reaction by the military regime to the defeat of General Augusto Pinochet in the 1988 Plebiscite since the system was formally established during the period between the plebiscite and the first postauthoritarian elections in 1989. This theory, however, offers a mistaken account of the history and evolution of the binominal election system whose origins are considerably more complex than the conventional wisdom suggests. This article explores the internal political processes and the ideology that led the military government to adopt the binominal system. It argues that the election system was the capstone of the authoritarian institutional framework designed by the military government to protect the 1980 Constitution from efforts by the Concertación to reform it. Contrary to popular belief, the binominal system was proposed long before the 1988 Plebiscite by Arturo Marin Vicuña, then secretary of a government commission studying a new electoral law. This article maintains that, more than any other factor, the binominal system reflects and responds to an interpretation of Chilean political history between 1960 and 1973 that was widely shared among the Pinochet government's legal advisors.
\end{abstract}

\author{
PALABRAS CLAVE • Binominal Election System • Electoral System • Authoritarian Enclaves \\ - Protected Democracy • Constitution of $1980 \bullet 1988$ Plebiscite
}

\section{INTRODUCTION}

On March 11, 1990, Chileans witnessed the end of seventeen years of military dictatorship with the inauguration of Christian Democrat Patricio Aylwin as the country's first democratically elected president since Salvador Allende in 1970. For the outgoing military government and its supporters, the transfer of the presidential sash from authoritarian leader General Augusto Pinochet to the freely elected President Aylwin represented the end of a successful democratic transition carried

* The author would like to thank Tomás Chuaqui, David Altman, Óscar Godoy, and two anonymous reviewers for their comments on this article. 
out in peace. For the incoming civilian government and its political allies in the Concertación de Partidos por la Democracia (Coalition of Parties for Democracy or simply the Concertación), the moment marked only the beginning of the transition to authentic democracy. The political regime the Aylwin government inherited from Pinochet differed markedly from the one established by the Constitution of 1925 that governed Chilean politics during one of the longest periods of democratic rule in Latin American history prior to the military coup of 11 September 1973. The 1980 Constitution promulgated by the military government created an institutional framework of limited, protected democracy, characterized by a new electoral system designed to limit the number of political parties in Congress, presidential control of the legislative process, and additional authoritarian enclaves to ensure "military tutelage and veto power over the decisions of civilian authorities" (Siavelis, 2000: xiv).

This article argues that the military government devised the congressional binominal election system as the linchpin of the authoritarian institutional framework protecting the 1980 Constitution and its corresponding constitutional organic laws from efforts to reform them by the Concertación. In order to do so, the following two sections examine the authoritarian enclaves within the historical context of the 1980 Constitution and the Chilean transition to democracy. Sections four and five discuss the design of the binominal election system and the mechanics of its operation. Finally, section six draws on official documents and interviews conducted by the author to shed light on the origins of the binominal system during the dictatorship.

\section{PROTECTED DEMOCRACY AND THE 1980 CONSTITUTION}

In July 1977, General Pinochet announced the Chacarillas Plan to move Chile toward his vision of an appropriate new political order: protected democracy (EI Mercurio, 1977: 33). The 1980 Constitution embodied Pinochet's ambition to overhaul the legal and political foundations of the nation. Written by a group of conservative jurists led by Jaime Guzmán, the charismatic Professor of Constitutional Law at the Catholic University in Santiago, inveterate Pinochet supporter, and leading intellectual associated with the military government, the new constitution provided for a strong presidency with eight-year terms, a congress of restricted legislative powers with $1 / 3$ of the Senate nominated rather than elected, and a variety of novel institutional mechanisms to entrench military influence within an eventual civilian government. In keeping with the increasing personalization of the regime and concentration of power in Pinochet's hands, he would be the first President under the 1980 Constitution. At the end of his eight-year term (1980-1988), a plebiscite would be held to approve or to reject the military's candidate for the second term (1989-1997). Only then could congressional elections be held, along with presidential elections should the military's candidate be rejected in the plebiscite.

The 1980 Constitution was itself approved in a carefully managed referendum on 11 September 1980 amidst an aggressive propaganda campaign by the government that included severe restrictions on opposition organization and access to the media. Six million Chileans voted in the plebiscite with the official results showing $67 \%$ in favor of the new Constitution and $30 \%$ against it. The government claimed an overwhelming electoral mandate and dismissed opposition claims of intimidation and fraud by pointing to the official figure of $30 \%$ of voters who had voted against the proposed Constitution (Collier \& Sater, 1996: 364). 
The approval of the 1980 Constitution gave the dictatorship a semblance of legitimacy and instituted a new political and legal framework for the nation. It specified the content of protected democracy by making the Armed Forces the "guarantors of the institutional order" (Constitución, Article 90) and granting them a constitutional role in politics through the establishment of a number of institutions not subject to civilian control with the ability to affect political decision-making and legislation. Among these authoritarian enclaves, the most striking may be the constitutional prohibition that forbids the President of the Republic from removing the commanders-in-chief of the various branches of the Armed Forces (Constitución, Article 93). Although the President has the authority to name new commanders-in-chief, once a serving commander's term has expired, they must be chosen from among the five most senior generals and, once appointed, the President cannot remove the serving heads of the Army, Navy, Air Force, and Carabineros (national police) without the consent of the National Security Council, which given its composition (discussed below), makes a dismissal unlikely. The lack of civilian control over military commanders, a basic criterion of political democracy, raises the question, to be addressed in the next section of this article, of whether the Chilean transition to democracy has been completed.

The unremovability (inamovilidad) of serving military commanders guaranteed that Pinochet would not just simply fade away after his defeat in the October 1988 plebiscite for a second eight-year term. Instead, he simply moved his office across the street to the Ministry of Defense and continued to serve as Army commander ignoring public calls and not so subtle hints from President Aylwin that he ought to resign (Loveman, 2000: 312). Since Pinochet stepped down as Army commander in 1998, overt acts of military insubordination have waned, and, with the leadership of current Army commander Juan Emilio Cheyre, civil-military relations have reached their highest point since the return of democracy. Still, the President's inability to sanction or remove high-level military officers who defy executive authority constitutes a latent challenge to democratic authority with potentially grave destabilizing effects on the political system.

A second authoritarian enclave embedded in the 1980 Constitution is the National Security Council, which must approve any presidential decision to remove one of the heads of the Armed Forces. Its members include the President of the Republic, the President of the Senate, the President of the Supreme Court, the Comptroller General of the Republic, and the four commanders-in-chief of the Armed Forces and the Carabineros. The Constitution charges the Council with making its opinion known to any official of the government regarding any "event, act, or subject matter, which in its judgment gravely challenges the bases of the institutional order or could threaten national security" (Constitución, Article 96). Prior to the 1989 constitutional reforms negotiated between the Concertación and the military government following the triumph of the 'No' in the plebiscite on Pinochet's continued rule until 1998, the Comptroller General was not included as a member of the Council and military officers had an absolute majority. The Concertación insisted that the Comptroller General be added to the Council so that the military officers would need the vote of at least one civilian to reach decisions (Siavelis, 2000: 38). Nevertheless, since the Comptroller of the Republic and the President of the Supreme Court are appointed positions, unelected members constitute a majority of the Council.

The Constitution Tribunal functions as a third authoritarian enclave that the designers of the 1980 Constitution created to restrict the powers of the President and Congress. The Constitution endows this body with the authority to make binding decisions on the constitutionality of existing laws, legislation at any point in the legislative process, and presidential decrees. It serves as the court of 
last resort, and there can be no appeal of its decisions. The Tribunal has seven members who serve staggered eight-year terms. The President and the Senate select one member each, the National Security Council two, and the Supreme Court three. Hence, the majority of the members receive their appointments from bodies that do not have a majority of elected members. Pinochet oversaw the appointments of all seven members of the Tribunal prior to 1990, but the Concertación has gradually been able to reshape the Tribunal's membership.

While the unremovability of the commanders-in-chief of the Armed Forces and the composition of the other two semi-autonomous institutions-the National Security Council and the Constitutional Tribunal-discount the democratic principle of civilian control of the state, the institutions of designated and lifelong senators strike at the heart of democratically elected institutions. The 1980 Constitution provides for nine designated senators (senadores designados) ${ }^{1}$ to serve for a period of eight years, ostensibly to bring a "neutral, apolitical, and 'mature' component" to the legislative branch (Siavelis, 2000: 39). Since allegedly, they would be beholden to no specific constituency, they would be able to rise above partisan concerns and to vote in the interests of the nation. The President has the authority to appoint two designated senators of whom one must be a former university president and the other a former minister of state. The Supreme Court designates three senators, and the National Security Council chooses four senators, each of whom must be a former commander in chief of a different branch of the Armed Forces: Army, Navy, Air Force, and Carabineros. The office of lifelong senator (senador vitalicio) pertains exclusively to former presidents who have governed for at least six years. Pinochet assumed the office in March 1998 after his tenure as commander of the army ended and held it until the Supreme Court stripped him of his congressional immunity from prosecution in August 2000. President Aylwin, having served only four years as a result of the 1989 constitutional accords reached between the military government and the Concertación, did not qualify to become a lifelong senator. ${ }^{2}$ At present, only ex-President Eduardo Frei Ruiz-Tagle, the second president from the Concertación, holds the office of lifelong senator.

The institutions of designated and lifelong senators grew out of Pinochet and the military government's disdain for professional politicians and political parties. Intended to impede efforts to reform the 1980 Constitution, Pinochet selected the first batch of designated Senators with the aim of giving the right-wing parties (RN and UDI) a majority in the Senate (Siavelis, 2000: 40). The strategy paid off during the first two presidencies of the Concertación denying the center-left coalition the majority it had won among the popularly elected senators. With the support of the designated senators, the Right had a majority in the Senate and succeeded in repelling all attempts at major constitutional reform during the Aylwin and Frei administrations.

The quorum requirements for constitutional reform represent a final element of the formula for protected democracy with limited popular sovereignty contained in the 1980 Constitution. A constitutional reform requires approval by the president and $3 / 5$ of the membership of both houses of Congress, not just those present and voting. Constitutional amendments affecting the powers of the president, constitutional rights and obligations, or the Armed Forces, the Constitutional Tribu-

The 1980 Constitution originally conceived of 26 popularly elected Senators. In the constitutional reforms negotiated with the military government following Pinochet's defeat in the 1988 plebiscite, the Concertación succeeded in raising the number to 38 , thus diluting the influence of the designated senators.

President Aylwin rejected an offer from the parties of the Right, Renovación Nacional (RN) and the Unión Demócrata Independiente (UDI), to amend the Constitution in order to make him a lifelong senator. 
nal, and the National Security Council ${ }^{3}$ call for a 2/3 majority in both houses. In addition, reforms to the constitutional organic laws (leyes orgánicas constitucionales), which spell out the details of important parts of the political regime like the electoral system that are not included in the Constitution, need a 4/7 majority to be ratified. By contrast, normal legislation requires an absolute majority. While the quorums for constitutional reform do not seem especially demanding when compared to those used in North American and European democracies, they pose a much greater obstacle to constitutional reform when considered in combination with the designated senators and a binominal electoral system, which was, as discussed below, designed to favor the Right.

The 1980 Constitution reflects the military government's low regard for popular sovereignty and its desire to protect the neoliberal socioeconomic model installed in Chile during the dictatorship. Its overriding preoccupation is social control: an autonomous military insulated from presidential authority, designated senators to guard against the supposed excesses of popular sovereignty, and a tutelary National Security Council charged with reviewing major government decisions. The 1980 Constitution not only makes the Armed Forces "guarantors of the institutional order," it also assigns them a salient role in politics through the nonelected semi-autonomous institutions, which give the Right a variety of vetoes over constitutional reform and policy initiatives.

\section{THE AUTHORITARIAN ENCLAVES AND THE TRANSITION TO DEMOCRACY}

The Aylwin government and the legislators of the Concertación assumed office in 1990 after swearing to defend the 1980 Constitution and its authoritarian institutional order that they considered illegitimate and had worked to undermine during the dictatorship. In a 1984 speech to the Constitutional Studies Group (Grupo de Estudios Constitucionales), Aylwin had argued that:

[following] the procedures for the transition in the 1980 Constitution will only serve to consolidate a regime of permanent dictatorship... On this road democracy is not reached. Accepting it is accepting the actual dictatorship and the authoritarian regime to which it leads. Doing this means renouncing the reestablishment of democracy (Aylwin in Loveman, 2000: 308).

Aylwin, however, was also the first leader within the Concertación to state publicly that peacefully recapturing political power from the dictatorship required the opposition to accept the illegitimate 1980 Constitution. The military government and the right-wing political parties certainly saw that as the bargain. Pinochet's last Minister of the Interior, Carlos Cáceres, negotiated a package of constitutional reforms to the 1980 Constitution with the Concertación after Pinochet's defeat in the 1988 plebiscite based on the premise that having the opposition coalition sign off on a set of limited constitutional reforms that were then approved by the electorate in a July 1989 plebiscite would more firmly entrench the authoritarian institutional order (Fernández, 1994: 314). ${ }^{4}$ Aylwin's gradualist view eventually prevailed within the Concertación as Pinochet remained impervious to calls for his resignation following the victory of the 'No' in the October 1988 plebiscite. Reluctantly, the Concertación accepted the major features of the authoritarian political order as the price of a peaceful transition to elected government and did its best to extract limited constitutional reforms from the military government.

The three semi-autonomous institutions.

Sergio Fernández, Cáceres' predecessor as Minister of the Interior for Pinochet describes the reasoning of the military government in his ironically titled memoirs: Mi lucha por la democracia. 
Aylwin's inauguration as president in March 1990 presented the nation and the leaders of the Concertación with a political paradox: a freely elected government forced to govern within an authoritarian institutional framework. Pinochet and the outgoing military regime declared the transition to democracy complete, "mission accomplished." On 11 September 1989, the anniversary of the coup, Pinochet announced to Chileans: "The Armed Forces have reconstructed authentic democracy" (Pinochet in Loveman, 2000: 307). The Concertación understandably felt otherwise; for its supporters, the transition was just beginning. The Aylwin government took office with a popular mandate- $55 \%$ of the popular vote-but under the shadow of an authoritarian resurgence. Far from inheriting an authentic democracy, it encountered a democratic situation amidst an authoritarian political landscape.

The new government faced three enormous tasks: transition, consolidation, and modernization. Completing the transition meant figuring out how to reform the authoritarian institutional enclaves within the 1980 Constitution. Consolidation entailed reinforcing the democratic consensus in society, especially by reintegrating the Right into politics in order to prevent an authoritarian regression. Modernization required maintaining economic growth while attempting to pay down the social debt to poor and marginalized Chileans left by the military government's single-minded focus on economic growth.

Lacking the votes in the Senate-where the designated senators appointed by Pinochet guaranteed the Right a majority-to pass a project of constitutional reform, Aylwin decided to focus on the tasks of consolidation and modernization. The strategy carried the risk of consolidating not only democratic government but also the authoritarian institutional framework implanted by the dictatorship (Garretón, 1995: 255). The danger materialized on 6 August 1991 when, without having achieved a single change in the authoritarian enclaves, Aylwin hastily announced: "Really, in my judgment, the transition is already complete. In Chile, we live in democracy" (Aylwin in Fernández, 1994: 326). In trying to conciliate the Right in order to foster the processes of democratic consolidation and modernization, Aylwin unintentionally strengthened the authoritarian institutional framework. Under this formula, as the threat of an authoritarian regression receded so too did the possibility of overcoming the authoritarian enclaves. Two years later, facing public saber rattling by Pinochet and the army and stymied by Congress in his effort to pass constitutional changes restoring the president's right to dismiss commanders-in-chief of the Armed Forces, abolish the designated senators, and change the binominal election system, Aylwin reversed himself and declared the transition incomplete, acknowledging that the Concertación would have to coexist within the authoritarian framework for the foreseeable future (Garretón, 1995: 255).

Presidents Aylwin and Frei left the central institutional tasks of the democratic transition unfinished. Both tried to pass constitutional reforms establishing civilian control over the military and strengthening popular sovereignty but found that they lacked the votes in Congress to reach the legislative quorums necessary to reform the 1980 Constitution..$^{5}$ Overcoming the authoritarian institutional legacies of the dictatorship has thus emerged as the most frustrating of the Concertación's political challenges. The remainder of this article explains why. It argues that the military government designed the binominal election system to prevent the Concertación from achieving the congressional majorities required to amend the 1980 Constitution. The military designers intended it to function as the linchpin of the authoritarian institutional framework holding

Current Chilean President Ricardo Lagos, though he regularly discusses the importance of the issue, has likewise been unable to negotiate a package of constitutional reforms with the Right. 
the various authoritarian enclaves together and preventing reforms to the 1980 Constitution without the agreement of the Right.

\section{THE BINOMINAL ELECTION SYSTEM}

The binominal formula for electing members of the Chamber of Deputies and the Senate did not appear in the 1980 Constitution although Article 45 stated that each of Chile's thirteen administrative regions would elect two senators. ${ }^{6}$ The article also stipulated that senators would serve eight-year terms and that the odd-numbered and even-numbered regions would elect senators in alternating four-year periods. ${ }^{7}$ Article 45 did not stipulate, however, that each electoral district (circunscripción) would constitute a single two-seat constituency -the so- called binominal system. ${ }^{8}$ It would also be consistent with the text of Article 45 to divide each electoral district into two singlemember districts for senatorial elections. In this hypothetical interpretation of Article 45, the Chilean senatorial election districts would resemble House of Representatives districts in the U.S. where each state is carved into multiple House districts with roughly equal populations. The analogous Chilean system would carve each administrative region into two distinct senatorial districts with roughly equal populations. The right-wing civilian jurists and politicians who designed the electoral system, and many of whom would later run for office under it, did not choose this interpretation of Article 45 for political reasons presented in the final section of this article.

Conversely, the senatorial election guidelines laid down by the 1980 Constitution might appear to resemble the system for senatorial elections in the United States where each state is a single electoral district that elects two senators. The Chilean system set forth in the 1980 Constitution, however, differs in that while U.S. states elect their two senators in alternating elections, the 1980 Chilean Constitution requires each region to elect all of its senators in the same election. While in theory it would be consistent with the 1980 Constitution to have two single-member independent senatorial districts for the same geographic area-administrative region-it seems unlikely that the framers of the 1980 Constitution considered it an option (Constitución, Article 45).

Law 18,700, (Constitutional Organic Law on Popular Elections and Vote Counting), approved by the military Junta on 6 May 1988, set forth the regulations governing future democratic elections and the formula for electing the President of the Republic to be used in 1989 and thereafter. Curiously, as promulgated in May of 1988, it failed to include the formula for electing members of the Chamber of Deputies and members of the Senate. The missing formula for congressional elections made its way into Law 18,700 over a year later, only after Pinochet's defeat in the October 1988 plebiscite, when the Junta approved Law 18,799, which inserted the binominal system into Law 18,700 through Article 109 bis. $^{9}$

6

The 1989 constitutional reforms divided six of the administrative regions into two electoral districts in order to increase the number of popularly elected senators. The Metropolitan Region of Santiago, for example, was divided into western and eastern electoral districts.

The Metropolitan Region of Santiago was included in the even-numbered group.

District Magnitude $=2$

Article 109 bis, Ley 18.700 in the Appendix of Constitución Política de la República de Chile. I am indebted to José Zalaquett for first drawing my attention to this important annex of the law. 
Article 109 bis formally adopted two-member districts for all legislative elections-both for the Chamber of Deputies and the Senate. This meant that every legislative election would fill two seats. Political parties or electoral coalitions of parties could run two candidates in each election on an open list where voters could choose the one candidate they preferred. The candidate with the most votes on the winning party list would claim one of the two seats. The other seat would go to the candidate with the most votes on the list of the party or coalition finishing second in the voting. The winning party or coalition could only capture both seats if it more than doubled the total number of votes received by the party or coalition finishing second. Assuming that there are only two coalitions competing in a particular district ${ }^{10}$, a coalition need receive only $33.4 \%$ of the vote to win one seat, while it must receive $66.7 \%$ of the vote to win both seats. In practice, this meant the Right could guarantee itself $50 \%$ of the seats in every district where it could win $33.4 \%$ of the vote. The seat-allocation formula clearly favored the second-largest party or coalition (the parties of the Right) during the first several elections as it was designed to do. "Any support a party receives above $33.4 \%$ but below $66.7 \%$ is effectively wasted" (Siavelis, 2000: 33-34). The designers of the system made the task of winning $33.4 \%$ of the vote even easier for the right-wing coalition by gerrymandering the electoral districts with that idea in mind. ${ }^{11}$

By making the final decisions on the formula for congressional elections and the boundaries of the electoral districts after the victory of the 'No' in the 1988 plebiscite, the designers of the electoral system were able to rely on crucial data afforded them by the plebiscite on Pinochet's continued rule: they knew fairly accurately the military government's level of support in every voting precinct across Chile. Almost $55 \%$ of voters backed the Concertación and voted 'No' in the plebiscite while roughly $43 \%$ of voters had supported General Pinochet and said 'Si' to eight more years of his rule. The designers reasonably assumed that Chileans who had stood behind Pinochet in the 1988 plebiscite would almost certainly vote for the Right in the December 1989 parliamentary elections and gerrymandered new electoral districts accordingly (Navia, 2003). Consistent with past electoral trends, Pinochet had garnered more support in the traditionally conservative rural areas than he had won in urban centers. Consequently, the designers divided the electoral map so that the 20 least-populated districts currently elect 40 deputies, while the 7 most-populated urban districts that have roughly the same population elect 14 deputies. The vote-per-seat ratio is also low in districts that supported Pinochet in the plebiscite and high in districts that the Concertación carried (Siavelis, 2000: 33).

\section{THE BINOMINAL SYSTEM IN ACTION: A CASE STUDY}

In the December 1989 legislative elections, Andrés Zaldivar-president of the Christian Democratic Party (DC)-and Ricardo Lagos-the leader of Chilean socialism and the founder of the Party for Democracy (PPD)-ran as the two candidates for Senate on the Concertación list for the western electoral district of Santiago, which includes many of the poorest communities of the capital. Both men enjoyed wide popularity and name recognition as two of the leading figures of the Concertación. The pair also shared a reputation for gifted oratorical and debating skills, but Lagos, in

10 In practice, third coalition lists other than those of the Concertación and the Right regularly win around $10 \%$ of the popular vote in many districts. This often lowers the binomial system's threshold for obtaining both seats in a district since to capture both seats, the winning coalition must double the vote total of only its nearest competitor.

This claim is discussed at greater length in the sixth section "Origins of the Binominal System." 
particular, had achieved national fame for pointing his finger at the camera and assailing Pinochet on national television, thereby, provoking a reaction of explosive rage in the General. Political commentators were convinced that Zaldivar and Lagos would demolish whichever candidates of the Right dared to challenge them in the Seventh Senatorial District, and Lagos appeared destined to preside over the future Senate.

The Unión Demócrata Independiente (UDI)-the party of the hard Pinochetista Right-found none of its members willing to challenge Zaldivar and Lagos in the Western District of Santiago. Several days before the filing deadline, Jaime Guzmán-founder of the UDI and the leading ideologue of the military government-agreed to enter the race even though he had resisted running for any elected office in 1989. He felt that the Right should not cede the field to the Concertación even within its stronghold. Guzmán, a talented speaker himself, relished the chance to take on two of the leading spokesmen of the anti-Pinochet coalition and remembered that the many men and women, especially women, from western Santiago who had supported the conservative government of Jorge Alessandri in 1958 provided him with a potential base of support (Salazar, 1994: 30).

Guzmán conducted an aggressive grassroots campaign establishing headquarters in each of the various comunas (municipalities) comprising the electoral district, sending out targeted direct mailings, and canvassing for votes at hundreds of community gatherings. In order to protect their president Andrés Zaldivar from Lagos' enormous popularity, the Christian Democrats fortified their existing network of grassroots organizations and campaigned intensively. Meanwhile, leading in the polls, greeted by crowds of adoring supporters wherever he went in the district, and assured by aides of his imminent victory, Lagos traveled up and down Chile stumping for PPD candidates (Salazar, 1994: 34).

Chileans went to the polls on 14 December 1989 to elect the first democratic president and congress since the 1973 coup. By the early morning hours of December 15, the results of the western Santiago senate election were known. On the Concertación electoral list, Zaldivar edged out Lagos by $0.7 \%$ of the total vote or 8,506 votes out of the 807,948 votes cast for the Concertación candidates. The Concertación captured $61.9 \%$ of the vote with Zaldivar claiming $31.3 \%$ and Lagos taking $30.6 \%$. The right-wing coalition between UDI and Renovación Nacional-Democracia y Progreso-won 32.5\% of the vote. Guzmán led the list with 17.2\% and Miguel Otero, the candidate of the more moderate center-right party Renovación Nacional (RN) claimed 15.3\% (see Table 1 below).

The winners of the election were Andrés Zaldivar and Jaime Guzmán. Even though Ricardo Lagos received a higher number and higher percentage of votes than either candidate of the Right, the Concertación list did not double the number of votes the Democracia y Progreso list obtained. Lagos had beaten Guzmán by 175,325 votes, but the binominal electoral system imposed by the dictatorship, and accepted by the Concertación as part of the price for a peaceful transition to democracy, made Guzmán the winner. 
TABLE 1: Senatorial Election Results for Circunscripción 7, Western Santiago (1989). Concertación and Democracia y Progreso Coalition Lists

\begin{tabular}{lcc}
\hline Concertación & Total & \% Vote \\
\hline Andrés Zaldívar & 408,227 & 31.3 \\
Ricardo Lagos & 399,721 & 30.6 \\
Total & 807,948 & 61.9 \\
& & \\
\hline Democracia y Progreso & Total & \% Vote \\
\hline Jaime Guzmán & 224,396 & 17.2 \\
Miguel Otero & 199,856 & 15.3 \\
Total & 424,252 & 32.5 \\
& & \\
\hline Other lists & 73,269 & 5.6 \\
\hline
\end{tabular}

Source: Servicio Electoral de Chile; table adapted from Siavelis (2000)

Of all the senators elected in December 1989, only Eduardo Frei Ruiz Tagle and Andrés Zaldivar received more votes than Lagos, but nonetheless, the forceful leader of the PPD had been shut out of the Senate. Most Chileans considered it a travesty that the RN candidate from Aysén in the far south of Chile, Hugo Ortiz de Filippi, would enter the Senate having garnered a little less than 9,000 votes while Lagos would remain outside the chamber in spite of having won nearly 400,000 votes (Salazar, 1994: 45).

The binominal system functioned as its designers had intended. In its political stronghold, the Concertación had failed to double the vote total of the Right by only slightly more than 35,000 votes and would be forced to share one of the district's two senate seats with one of its most despised enemies: the principal spokesman, the great apologist, and the leading architect of the authoritarian institutional order, Jaime Guzmán (Zaldivar, 1995: 303). The Right had captured less than $1 / 3$ of the popular vote but would obtain $50 \%$ of the district's senate seats.

\section{THE ORIGINS OF THE BINOMINAL SYSTEM}

Many Chilean politicians, scholars, and international observers have assumed that the military government reacted to Pinochet's defeat in the October 1988 plebiscite by devising the binominal system to prevent the Concertación from sweeping the December 1989 congressional elections. According to this view, the Right panicked in the aftermath of the plebiscite and began searching for a way to secure enough representation in the future congress to veto constitutional reforms proposed by the Concertación. The Right had good reason to worry. The Concertación prevailed in the plebiscite with $55 \%$ of the vote to Pinochet's $43 \%$, and since that margin reflected roughly the 
balance of power across the entire country (there being few major regional cleavages), it was possible that, with a single-member district system, the Right could be effectively shut out of Congress (Siavelis, 1997: 657). Indeed, had the 60 electoral districts for the Chamber of Deputies, gerrymandered by the military government to maximize support the Right, been single-member districts, the Concertación would have won 55 of them (91.7\%) in 1989. In the Senate, singlemember districts would have allowed the Concertación to sweep all 19 of the senatorial districts (Navia, 2003). ${ }^{12}$ Even counting the 9 designated senators, with all 19 elected senators, the Concertación would have had more than the quorums needed in both chambers of Congress to pass constitutional reforms dismantling the authoritarian framework of the 1980 Constitution.

Consequently, those who think that the binominal system was a simple reaction to Pinochet's loss in the plebiscite suggest that the military regime and its civilian allies adopted the binominal system with three objectives in mind. First and foremost, they wanted to insure that the Right would be well represented in Congress so that it would have a veto over constitutional reforms and policy initiatives proposed by the Concertación. Second, the architects of the binominal system wanted to impose a two-party political system in Chile in which the Christian Democratic Party (DC) would be forced to align itself with the Left or the Right. Third, the authoritarian designers wanted to deprive the Communist Party of representation (García, 2002: interview). ${ }^{13}$ Finally, observers have assumed that Jaime Guzmán played the leading role in the creation of the binominal system as he did in the writing of the 1980 Constitution (Sánchez, 2002: interview). ${ }^{14}$

The theory that the binominal system was a response to Pinochet's loss in the plebiscite correctly identifies many of the political considerations that led the Pinochet government and its allies to adopt the binominal election system but errs in its account of the historical evolution of the system. Moreover, while Jaime Guzmán provided important backing for the binominal system within the military regime, he neither created the binominal system nor wrote the legislation enacting it. The chronology of the system from the time the idea was first presented to the military regime until the Junta passed Law 18,799 on 26 May 1989 is considerably longer than the conventional wisdom supposes.

The historical antecedents of the binominal system date back to the creation of the Commission for the Study of a New Constitution by the newly ensconced military government in the waning months of 1973. The Junta believed that the proportional representation (PR) system established by the 1925 Constitution had led to a proliferation in the number of political parties. The intensity of the resulting electoral competition was, in the Junta's view, a leading cause of the political fragmentation and polarization that preceded the election of Allende in 1970 and eventually resulted in the military coup of 11 September 1973. ${ }^{15}$ The government asked the Commission to study and propose a draft of a new constitution, which would prevent the political events of the 1970-1973 period from ever occurring again. The Ortúzar Commission, as it came to be known, formed several subcommittees to consider specific subjects, one of which was the electoral system. Nevertheless, the electoral subcommittee declined to recommend a specific electoral system and

The claim is made on the basis of electoral simulations.

Interview with Juan Ignacio Garcia, Director of the Electoral Service of Chile

Professor Gonzalo Rojas Sánchez, considered by some to be the semi-official historian of the military government, among others asserted that Guzmán devised the system.

15 For a detailed analysis of this process, see Valenzuela (1978). 
instead discussed the options of the single-member district majority system and different proportional systems in its report.

The full Commission for the Study of a New Constitution finished its work in October of 1978 (after Pinochet had consolidated his personal control over the regime) and delivered the proposed text of a new Constitution to Pinochet. In its discussions regarding the Congress, the Commission had debated different methods for electing legislators but decided not to include a concrete electoral proposal in its draft constitution. In its report, though, the Commission rejected the reinstatement of a PR system and expressed its preference for a majoritarian system, the details of which, it left vague. The Commission simply noted that "the electoral system ought to result in the effective expression of majorities through uninominal districts or polynomial districts that elect the same number of deputies" (Antecedentes, 1981: 257). The Commission recommended that the Chamber of Deputies include 150 elected members and that each of the thirteen administrative regions elect two senators. The provision suggesting the election of two senators by each region has prompted at least one scholar to argue that the framers of the 1980 Constitution already had the binominal system in mind for electing the members of the upper chamber (Navia, 2002). This seems unlikely, however, since the proceedings and reports of the Commission for the Study of a New Constitution contain no reference to a binominal system and because the members of the Commission who went on to serve on the subsequent Advisory Commission on Constitutional Organic Laws did not propose the binominal system to that body.

Pinochet sent the Commission on Constitutional Reform's draft proposal to the Council of State, a civilian advisory group, for comment and revisions. The Council of State, chaired by former conservative president Jorge Alessandri, made extensive revisions to the earlier draft before sending a new draft back to Pinochet in July of 1980. It maintained the idea that each region should elect two senators as a general norm, but suggested that the two second most populated regions-the $5^{\text {th }}$ Region (Valparaíso) and the $8^{\text {th }}$ Region (Concepción)-should elect three senators each and that the most populated region-the Metropolitan Region of Santiago-ought to elect six senators. With respect to the Chamber of Deputies, it proposed 120 single-member districts whose representatives would be elected by majority vote with a second round if necessary (Antecedentes, 1981: 401).

The Council of State's revisions were deemed excessively liberal by the Pinochet and his advisors, who proceeded to make their own modifications to the proposal, especially regarding the time frame for democratic restoration. Alessandri resigned from the Council of State in disgust. The amended version of the Executive called for a Chamber of Deputies whose membership would be elected according to an unspecified future constitutional organic law and for a Senate comprised of two members elected by each of the 13 regions and nine designated members. The military government made the new draft constitution public on 11 August 1980 and called for its approval in a plebiscite to be held on 11 September 1980. After being "approved" in a tightly managed plebiscite, the new authoritarian constitution went into effect on 11 March 1981 (Collier \& Sater, 1996: 364).

The first election envisioned in the 1980 Constitution was not scheduled to take place until December of 1989. While it seemed remote to the military government, Pinochet asked the Council of State to begin studying a new electoral law. Meanwhile, in March of 1983, the military government created the Advisory Commission on Constitutional Organic Laws, chaired by Pinochet's ex-minister of the Interior Sergio Fernández, to study and propose all of the complementary laws called for by 
the 1980 Constitution, of which the electoral law was one. Since the mandates of the Council of State and the Advisory Commission on Constitutional Organic Laws overlapped in this area, they decided to form a subcommittee of the Council of State whose members would be drawn from both bodies to study a new electoral law. The members from the Council of State included Francisco Bulnes (a former conservative senator), Julio Chaná (a professor of law at the Catholic University and a former minister of state), Pedro Ibáñez (a former rightist senator of the Liberal Party), and Juan Antonio Coloma (a current UDI senator). The members drawn from the Commission on Constitutional Organic Laws were Hermógenes Pérez de Arce (a former deputy and well-known El Mercurio columnist), Jaime Guzmán (then a Professor of Law at the Catholic University and the leading figure in the writing of the 1980 Constitution), Gustavo Cuevas (then director of the University of Chile's Institute of Political Science), Luz Bulnes (then a Professor of Law at the University of Chile), and, acting as secretary of the committee, Arturo Marín (a lawyer and an advisor to Fernández).

At the subcommittee's first meeting in 1984, Marín proposed the binominal election system and offered an analysis of why he believed the proportional representation (PR) system had resulted in the breakdown of democracy in 1973 and how the binominal system would prevent the recurrence of such a scenario in the future (Marin, 2002b). ${ }^{16}$ He argued that the problem with Chilean Democracy between 1960 and 1973 had been the electoral emergence of the Christian Democratic Party (DC) masquerading as a centrist party in elections and then pursuing leftist policies during the government of Eduardo Frei Montalva. He felt that Eduardo Frei and the DC had won the 1964 presidential election with the support of the Right but then had governed like a leftist party, pursuing agrarian reform and nationalizing various industries including the copper mines. In fact, the copper mines would not be nationalized until 1971 under the Allende government. Under Frei's "Chileanization" program, however, the state did obtain a majority stake in the copper mines. Moreover, Marín's evaluation of the Frei government is uncharitable at best given that Frei presented himself as a Catholic social reformer and vowed not to change the DC's platform even for a million votes from the Right. In the 1970 presidential election, according to Marin, the DC hoped to capture the support of the Right again with a program that the Christian Democrats' own candidate, Radomiro Tomic, claimed was more leftist than that of Allende. This time the Right was loathe to support a Christian Democrat for President, even to prevent a victory by the Left, and Allende won a plurality of the popular vote.

Marin claimed that the DC had attracted the support of moderate voters because the PR system, with many congressional seats to be elected in each district, left voters confused, uncertain of how to vote given so many options. ${ }^{17}$ The voters, consequently, gave the DC more support than it would have won in a more moderate party system because the party appeared "quantitatively" situated between the extremes of the oligarchical National Party on the Right and the Marxist parties on the Left. To demonstrate how the PR system had obscured the "qualitative" center of the political spectrum, Marin offered the case of a retired grandmother who lived modestly and valued her right to ownership of a small house. Under the PR system, she felt inclined to vote for a Christian Democratic candidate who professed to be Catholic and centrist even though, once elected, that candidate would advocate confiscations, expropriations, price controls, and high

16 To Marin's knowledge, the meeting marked the first time that the idea of a binominal election system was discussed in the military government.

17 Analysts of Chilean politics have noted that the PR system prior to 1973 did lead to a certain degree of party-system fragmentation "given the electoral system's permissiveness in the representation of small parties" (Siavelis, 2000: 32). 
taxes on the upper class. In Marín's estimation, the Right defended her values and interests, but within the vast spectrum of political parties generated by the PR system, the Right appeared extremist. Marín contended that by dividing the political spectrum into a three-thirds configuration (tres tercios), the PR system had allowed the DC to capture votes from both the Left and the Right without adopting a clear ideological posture. This claim, however, is at odds with the literature on Chile which points to the emergence of the DC in the 1960s as a centrist party with its own ideology-a type of Christian communitarianism-as an important factor contributing to the ideological polarization and party-system fragmentation that ultimately led to the breakdown of democracy in 1973. The DC displaced the pragmatic, non-ideological, and coalition-oriented Radical Party as the dominant party of the Center and sought to govern by itself (partido único)-eschewing a coalition with the Left or the Right. ${ }^{18}$ Evincing deep personal animosity toward the DC, shared by the members of the subcommittee no doubt, Marín maintained that the party "made people forget the two great options every society has in confronting political and social problems: statism or individual liberties" (Marín, 2002a).

By contrast, Marín believed a majoritarian electoral system would forestall ideological confusion and ensure "real" moderation in candidates' positions. With few seats up for election in each district, a majoritarian electoral system would impose a dynamic of centripetal competition, party system integration, and the eventual establishment of a two-party system or limited multipartism (Siavelis, 1997: 656). Voters would have fewer candidates to choose among and, therefore, would be capable of better distinguishing between them. Marin ruled out the single-member district system on the grounds that the system would likely deliver all of the elected seats in Congress to the opposition in the first democratic election. That left the binominal system as the best option for the military government and the Right. Marín accompanied his presentation to the subcommittee with diagrams and figures analyzing the electoral system during the period 1960-1973 and showing projections of the balance of power that could be expected in a future Congress elected using the binominal system.

This highly paternalistic electoral analysis met with great enthusiasm from Jaime Guzmán and Hermógenes Pérez de Arce, arguably the two most authoritarian members of the committee. Francisco Bulnes, one of the most influential members of the traditional Right, also expressed his approval on this occasion. Marin left the meeting believing that the committee would reach a consensus on the binominal system as the most desirable formula for future congressional elections after the restoration of democracy in Chile. By the committee's second meeting, however, Bulnes had changed his mind and announced his opposition to the binominal system and his preference for a PR system, which he did not describe, but which appeared to resemble the PR system in effect up to 1973 with some modifications that he never specified. From then on, the result of the committee's deliberations on a new electoral system remained uncertain (Marín, 2002).

In 1984, as part of its ongoing discussions on the electoral system, the joint subcommittee invited then Minister of the Interior Sergio Onofre Jarpa to one of its meetings. Queried about his preference for the future electoral system, Jarpa argued for the binominal system because it could be expected to contribute to the formation of two great political blocs (Clavel et al., 2002: 315). While the joint subcommittee of the Council of State continued to debate the future electoral system, Marin drew a preliminary map of new electoral districts for the Chamber of Deputies considering: the population 
over age eighteen in each district according to figures kept by the National Institute of Statistics and calculated on the basis of the 1982 Census and projections of population growth since 1982, the administrative divisions of Chile-using the criterion of uniting comunas (municipalities) or provinces within the same region so that each district could elect two deputies, and the population density of districts with the idea that one deputy would be assigned for every 90,000 people and fraction thereof not below 45,000 people. In Santiago, where more than 1/3 of the population lived, one deputy would be allotted for every 120,000 inhabitants and fraction thereof not below 60,000 inhabitants.

Within the total scheme, Santiago would elect 40 deputies and all the other regions together would elect 80 deputies. Thus, despite its large population and national importance, Santiago would be significantly underrepresented in the future Congress. At this early stage of the districting process, Marin claims to have focused on the technical criteria outlined above, knowing that the draft would undergo extensive revision later in light of political considerations, but his deliberate underrepresentation of Santiago belies this claim. Marin gave the districting plan to Rafael Valdivieso, secretary of the Council of State, who began the political revisions. Valdivieso went through five more drafts before arriving at a sixth and final draft.

In March of 1985, the joint subcommittee on the electoral system finished its work and sent a note to Pinochet with its basic principles and preliminary conclusions. The note stated that the committee, not knowing the preferences of the President and the Junta, had not taken a definitive position on which electoral system to adopt. Referring to the dangers of PR systems that fragmented public opinion excessively, however, the committee expressed its inclination toward the binominal system. The note indicated that the committee would await the input of the President and the Junta before choosing an electoral system and drawing up the appropriate legislation.

Pinochet never answered the note that the Council of State sent him on behalf of the subcommittee. In practice, this meant that the Council of State should abstain from studying the electoral system further, and initiative passed entirely into the hands of the Advisory Commission on Constitutional Organic Laws. According to Marín, there were two reasons for this development. First, the Council of State was made up of older men who were reluctant to try new and untested electoral formulas. Second, Sergio Fernández, who enjoyed Pinochet's confidence as his former Minister of the Interior, felt that it was easier to handle the matter in the Advisory Commission on Organic Constitutional Laws where, as chairman, his opinion would have greater weight.

While the Fernández Commission continued deliberations on the topic, Marín presented the idea of a binominal electoral system to an academic audience at a conference on the options for a future Chilean electoral system held by the Institute of Political Science of the University of Chile on 14 January 1986 (Marín, 1986). ${ }^{19}$ He argued that the critical defect of the PR system during the decade from 1963 to 1973 had been its tendency to allow the proliferation of political parties competing to claim the mantle of the Left, which perpetuated the continued weakness of the Right. As the "quantitative center" of the political spectrum shifted toward the Left, in terms of the number of radicalized political parties, its movement obscured the moderate, fixed, "qualitative center" of the political spectrum. This process resulted in the classification of what, in Marin's view, would 
normally be considered a leftist political party (the DC) as a centrist party. From 1963 to 1973 "leftist parties were called centrist and the extreme Left was referred to simply as the Left" (Marín, 1986: 142). At the same time, the combination of the PR system and the increasing radicalization of Chilean politics condemned the Center-Right to slim representation and little influence in shaping legislative decisions.

Marin suggested that the binominal system-the simultaneous election of two candidates in each district- would produce a "centripetal" tendency toward moderation and the qualitative center of the political spectrum because candidates would find it difficult to secure enough votes solely among their parties' traditional supporters to win one of only two seats per district and, therefore, would have to appeal to moderate independents or voters from other parties. Moreover, the political parties would reinforce the centripetal tendency of the system by selecting candidates attractive to a wide variety of voters. Assuming that the extremes of the political spectrum represent minorities, the candidates who could attract the widest possible base of support would normally be centrists. ${ }^{20}$ Marin's contention that the binominal system produces a dynamic of centripetal has since been called into question by several political scientists (Magar et al., 1998). They have made a formal argument based on spatial modeling and game theory that the binominal system does not encourage centripetal competition and, in fact, offers candidates "incentives to adopt positions away from the median voter" (Magar et al., 1998: 715). In addition, Marín argued that the binominal system would present incentives for party system integration or the formation of electoral coalitions of parties. He contended that both of these phenomena would better represent the two great historical lines of political thought (Left and Right), while minimizing local nuances, factions, and leaders. Most importantly, the centralizing, moderating effects of the binominal system would make it less difficult to identify leftist candidates or parties masquerading as centrists (Marín, 1986: 142-143).

In the short term, Marin predicted that the binominal system would not have the desired party integration and centralizing effects on the political system. He conceded that in the 1989 elections, the Left could conceivably win the congressional seats necessary to destroy the "pillars of the regime," given the level of popular support that it commanded, but added that any democratic electoral regime presented that possibility (Marin, 1986: 144). By the second parliamentary election, however, he suggested that supporters of the military government could hope to see the reductive and centralizing effects of the binominal system because an opposition sweep in the first parliamentary election would make a split in the Left likely as its more moderate elements sought to distinguish themselves from more extreme factions. If the leftist opposition did not split, the Right might even have the chance "to win the second or third election" (Marín, 1986: 143). ${ }^{21}$ Marín concluded by assuring the audience that, in any case, the Right could rely upon the continued presence of the Armed Forces in politics to guard against any unintended effects of the binominal system.

With the decision on the electoral system now in the hands of the Advisory Commission on Constitutional Organic Laws, Fernández asked Marín to draw up the text of a binominal electoral

20 Marín's arguments might seem to be based upon the classic theoretical literature concerning the effects electoral systems have on party systems (e.g. Duverger, Sartori, and Downs); however, when interviewed, Marín claimed to have no training in political science and to be unfamiliar with the relevant literature. On the basis of our conversations, this author is inclined to believe him.

${ }^{21} \quad$ None of this actually occurred. The Concertación has held together as a coalition and maintained a majority in the Chamber of Deputies and a majority of the Senate's elected members through the first four congressional elections. 
law. This draft law included the electoral districts, registration and vote counting procedures, and the rules governing seat allocation under the binominal system. These topics were later separated into three different laws: Law 18,556, Law 18,700, and Law 18,799 respectively. Since the electoral districts, voter registration procedures, and vote counting procedures had to be approved well in advance of the elections, the issue of seat allocation was left as the last law to be passed by the Junta and promulgated by Pinochet.

When the moment arrived for the Advisory Commission to vote on the text of the binominal electoral law written by Marin and the 60 binominal districts contained in the sixth version of the electoral map drawn up by Rafael Valdivieso, the membership of the Commission had changed significantly. The chairman Sergio Fernández remained as did Jaime Guzmán, Luz Bulnes, and Gustavo Cuevas, but Gustavo Alessandri (a former rightist deputy), Guillermo Bruna (Professor of Law at the Catholic University), Juan de Dios Carmona (former Minister of Defense under Frei Montalva), and Patricio Prieto (a lawyer with the firm Prieto \& Cía) had replaced the other original members of the Commission. Alessandri and Bruna led a revolt within the committee arguing against the binominal system and for a PR system. Carmona, Prieto, Bulnes, and Cuevas remained in doubt. Fernández and Guzmán fiercely defended the binominal system. After lengthy debate, the binominal proposal finally passed on a close vote.

In 1987, Fernández reassumed his former position as Minister of the Interior as Pinochet prepared for the 1988 Plebiscite. Fernández requested that Marin draft a final electoral law, based on the binominal proposal approved by the Advisory Commission on Constitutional Organic Laws, for Pinochet to sign and send to the Junta as official legislation. According to Marín, however, one final twist remained. Desiring to give the regions greater electoral representation, Fernández or another advisor of his, Carlos Goñi, devised a new electoral scheme that divided Chile into four macroregions, each of which would receive equal representation in the Chamber of Deputies. The plan called for Chile's administrative regions to be grouped together in the following form: the Northern Macro-Region (Regions I, II, III, and IV), the Metropolitan Macro-Region (Region V and Santiago), the South Central Macro-Region (Regions VI, VII, VIII, and IX), and the far South Macro-Region (Regions $X, X I$, and XII). Supposedly, Fernández justified the plan as necessary to combat the traditional and pernicious centralization of government in Chile. At the same time, however, the plan provided a great electoral boon to the Right by significantly overrepresenting rural areas and grossly underrepresenting the population of Santiago. Pinochet signed Fernández's proposal and sent it to the Junta for approval in mid 1988 (Marín, 2002a).

On 5 October 1988, Pinochet lost his bid for a second eight-year term in the plebiscite. A united political opposition campaign by the Concertación helped persuade $55 \%$ of voters to support the 'No'. A month after the plebiscite, Fernández resigned and Carlos Cáceres succeeded him as Minister of the Interior, appointing Marín to head his cabinet. Cáceres and Marín convinced Pinochet to modify the macro-region electoral law pending before the Junta and to replace it with the 60 binominal district system designed by Marín and Valdivieso. Cáceres and Marín then immediately hired Jaime Egaña Barahona and Jaime Egaña Respaldiza, whose article about the electoral districts they had read that day in El Mercurio. The technicians set about gerrymandering the electoral districts one last time, and several days later, in December 1988, Pinochet presented a note to the Junta formally changing the pending electoral law to the binominal system. 
The military government made the proposal public and Ricardo Lagos began attacking it as an effort to redraw the electoral districts in light of the plebiscite to favor Pinochetismo in the coming elections. The criticism was absolutely true, but the irony of the situation was that although the districts had been gerrymandered both before and after the plebiscite, the binominal proposal was arguably much better for the Concertación's electoral fortunes than the macro-regions proposal that it replaced. The regime did not respond to Lagos' charges since it was preoccupied negotiating a package of limited constitutional reforms with the Concertación and wanted to keep tensions as low as possible (Marín, 2002a). In hindsight, it seems likely that Lagos' accusations gave rise to the idea that the dictatorship devised the binominal system as a direct response to Pinochet's loss in the plebiscite. The only real difference, however, between the conventional wisdom and events described in this article is one of chronology. The Concertación understood all too well the authoritarian motives behind the military government's adoption of the binominal system and probable effect the new electoral system would have on transition politics.

In March 1989, the joint legislative commission of the Junta began considering the binominal system electoral law. ${ }^{22}$ Marin attended the proceedings as the representative of the Executive. There was no discussion of the rationale behind the binominal system. The joint legislative commission made some minor suggestions about the composition of several electoral districts and sent the proposal to the Junta for final approval. After hearing from the political parties, especially RN and the DC, the Junta amended the law to allow electoral pacts in which two or more parties would share an electoral list with the intention of sharing votes in order to obtain the critical thresholds established by the binominal system. ${ }^{23}$ Pinochet immediately accepted the Junta's decision to allow electoral coalitions. The Junta approved Law 18,799 formally enacting the binominal electoral system on 26 May 1989.

\section{CONCLUSION}

The military regime did not panic in the wake of General Pinochet's defeat at the polls in October 1988. Rather, it had been developing the authoritarian institutional framework that would tie the hands of the Concertación since the late 1970s. The binominal electoral system, under consideration since 1984, was designed to serve as a bulwark protecting the 1980 Constitution from reform efforts by the Concertación. Wanting to do away with the PR system but fearing that a singlemember majoritarian system would mean the reversal of the authoritarian institutional and economic project, Arturo Marín devised the ingenious binominal system to overrepresent the Right in Congress, giving it a veto over the constitutional and legislative initiatives of the Concertación. The persistence of the 1980 Constitution's authoritarian enclaves and the binominal election system more than a decade after the return to democratic government speaks to the success of his project. No major constitutional reforms are possible without the agreement of the Right.

22 The four legislative commissions corresponding to each member of the Junta (the Commanders-in-chief of the Navy, the Air Force, and the Carabineros as well as the Vice-Commander of the Army) had previously considered the law separately and designated members for the conference committee.

23 This modification to the law has proven extremely important to postauthoritarian politics since it has resulted in a bipolar pattern of competition between two large coalitions: the Concertación (Center-Left) and the Alianza por Chile (Right) which has had several prior names. 
Since 1989, the Concertación and the Right have negotiated a series of limited, yet significant, constitutional reforms. The binominal election system, however, has consistently proven to be a stumbling block. So much so that recent promising negotiations between the Lagos government and the Right on major constitutional reforms-including the elimination of the designated senators and the restoration of the President's ability to dismiss military commanders-broke down over disagreements over the future of the binominal system (La Tercera, 2004, May 4). President Lagos felt so strongly about the issue that in his 21 May 2004 State of the Nation Address, he told Chileans: "The binominal system will be the death of our democratic system... You elect one, and I elect the other... Under this electoral system, the voter's decision becomes increasingly irrelevant" (El Mercurio, 2004: C6). This account of the origins of the binominal system is offered as a contribution to the public debate on what electoral system is best for the future of Chilean democracy.

\section{REFERENCES}

Andrade Armijo, Julio. 1989. "Informe de la Cuarta Comisión Legislativa al secretario de legislación." In Historia de la ley 18.799. Santiago: Biblioteca del Congreso.

"Antecedentes de la Constitución de 1980." 1981. Revista Chilena de Derecho 8 (January-December).

Arancibia Clavel, Patricia; Claudia Arancibia Floody, et al. 2002. Jarpa: confesiones políticas. Santiago: La Tercera-Mondadori. Bruna, Guillermo. 2002. Interview. Santiago, 30 May.

Collier, Simon and William F. Sater. 1996. A History of Chile, 1808-1994. New York: Cambridge University Press.

Constitución Política de la República de Chile. 2000. 8th ed. Santiago: Editorial Jurídica de Chile.

Cruz-Coke Ossa, Carlos. 2000. "En defensa del sistema electoral mayoritario binominal de escrutinio político." Revista de Derecho Público 63: 530-542.

El Mercurio. 1977. "Anoche en Chacarillas: S.E. Indicó Grandes Líneas Institucionales." 10 July: 33.

El Mercurio. 2004. "Mensaje presidencial 2003-2004." 22 May: C4-C6.

Fernández, Sergio. 1994. Mi lucha por la democracia. Santiago: Editorial Los Andes.

García, Juan Ignacio. 2002. Interview. Santiago, 13 May.

Garretón, Manuel Antonio. 1995. "Transición incompleta y régimen consolidado: las paradojas de la democratización chilena." In Hacia una nueva era política: Estudio sobre las democratizaciones. Santiago: Fondo de Cultura.

Godoy, Óscar. 1990. "Algunas claves de la transición política en Chile." Estudios Públicos. 38: 141-148.

Godoy, Óscar. 1996. "Pueden las Fuerzas Armadas ser garantes de la democracia?" Estudios Públicos 61: 269-307.

Guzmán, Eugenio. 1993. "Reflexiones sobre el sistema binominal." Estudios Públicos 51: 303-330.

Huneeus, Carlos. 2000. El régimen de Pinochet. Santiago: Editorial Sudamericana Chilena.

La Tercera. 2004. "Sistema electoral vuelve a torpedear acuerdo sobre reformas constitucionales." 5 May: 4.

Loveman, Brian. 2001. Chile: The Legacy of Hispanic Capitalism. 3rd ed. New York: Oxford University Press.

Magar, Eric, Marc Rosenblum, and David Samuels. 1998. "On the Absence of Centripetal Incentives in Double-Member Districts:

The Case of Chile." Comparative Political Studies 31: 714-739.

Marín Vicuña, Arturo. 1986 "El sistema binominal como una opción para el centro político." Política 9: 139-145.

Marín Vicuña, Arturo. 2002a. "Cronología del sistema binominal." Personal correspondence. Santiago, 5 June.

Marín Vicuña, Arturo. 2002b. Interview. Santiago, 31 May.

Navia, Patricio. 2002. Personal correspondence. 17 May.

Navia, Patricio. 2003. You Select the Rules of the Game and Lose? Advantages and Constraints When Choosing Electoral Rules: The Case of Chile. Dissertation: New York University. http://home.nyu.edu/ pdn200/scholarly.html.

Rabkin, Rhoda. 1996. "Redemocratization, electoral engineering, and party strategies in Chile, 1989-1995." Comparative Political Studies 29(3): 335-356.

Rahat, Gideon and Mario Sznajder. 1998. "Electoral Engineering in Chile: the Electoral System and Limited Democracy." Electoral Studies 17(4): 429-442. 
Riquelme Segovia, Alfredo. 1993. "Los Márgenes de la Transición y la Democracia Desencantada." In Encuentro con América Latina: Historia y Literatura, edited by Sonia Mattalía and Joan Alcázar. Universidad de Valencia: Valencia, 211-229.

Riquelme Segovia, Alfredo. 1999. "Quiénes y por qué 'no están ni ahí: Marginación y/o automarginación en la democracia transicional. Chile 1988-1997." In El modelo chileno: Democracia y desarrollo en los noventa. Santiago: LOM, 261-279.

Rojas Sánchez, Gonzalo. 2002. Interview. Santiago, 13 May.

Salazar, Manuel. 1994. Guzmán: Quién, cómo, por qué. Santiago: Ediciones BAT.

Scully, Timothy. 1995. "Reconstituting Party Politics in Chile." In Building Democratic Institutions: Party Systems in Latin America, edited by Scott Mainwaring and Timothy Scully. Stanford: Stanford University Press, 100-137.

Timothy Scully. 1992. Rethinking the Center: Party Politics in Nineteenth and Twentieth Century Chile. Stanford: Stanford University Press.

"Seminario: Sistema Electoral y Congreso Nacional." 1988. Revista de Ciencia Política. Special Edition, September.

Siavelis, Peter and Arturo Valenzuela. 1996. "Electoral Engineering and Democratic Stability: The Legacy of Authoritarian Rule in Chile." In Institutional Design in New Democracies: Eastern Europe and Latin America, edited by Arend Liphart and Carlos Waisman. Colorado: Westview Press.

Siavelis, Peter. 1997. "Continuity and Change in the Chilean Party System: On the Transformational Effects of Electoral Reform." Comparative Political Studies 30: 651-674.

Siavelis, Peter. 2000. The President and Congress in Postauthoritarian Chile: Institutional Constraints to Democratic Consolidation. University Park, Pennsylvania: Pennsylvania State University Press.

Valenzuela, Arturo. 1978. The Breakdown of Democratic Regimes: Chile. Baltimore: Johns Hopkins University Press.

Valenzuela, Arturo and Peter Siavelis. 1991. "Ley electoral y estabilidad democrática: Un ejercicio de simulación para el caso de Chile." Estudios Públicos 43: 27-86.

Zaldívar L., Andrés. 1995. La transición inconclusa. Santiago: Editorial Los Andes.

Daniel Pastor received an A.B. in Politics from Princeton University where he was awarded the Martin A. Dale ' 53 Fellowship and a Fulbright Grant to Chile. Currently, he is a visiting researcher at the Institute of Political Science of the Pontificia Universidad Católica de Chile.

(E-mail: dpastor@fulbrightweb.org) 